\title{
Eine Täuferlegende.
}

In den Miracula S. Eustathii, aus dem Äthiopischen übersetzt von Turnaiew (CSCO, Scriptores Aethiopici, Series altera, Tomus 21, 1) liest man p. 78, V: bestiae fuerunt sicut eorum propinqui et cum is consociati et pacatae sunt sicut leones Babylonici in lacu cum Daniele propheta, et cum Johanne, filio Zachariae casto, cum audirent eum annunciantem verbum Evangelii in desertis Aennon et in desertis Sinai: tum inclinaverunt aures suas ad eum leones, ut nunciaret verbum oris sui, nąm Christum annunciabat, ferens Evangelium capite suo et vadens sine corpore et anima, alis Gabrieli angeli, inter caelum et terram, et dicens:

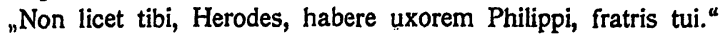

Woher stammt

1. die Angabe, daß Johannes in der Wüste des Sinai wirkte;

2. daß Löwen ihm zuhörten;

3. daß er von Gabriel durch die Luft getragen wurde?

Maulbronn.

Eb. Nestle. 